\title{
QUALITY MANAGEMENT IN THE METHODOLOGY OF DESIGNING ROTATION MECHANISMS FOR LARGE-SIZE MACHINES
}

\author{
${ }^{1}$ Marek KRYNKE, ${ }^{2}$ Krzysztof MIELCZAREK, ${ }^{3}$ Marta JAGUSIAK-KOCIK, ${ }^{4}$ Anna KIEŁBUS \\ ${ }^{1,2,3}$ Czestochowa University of Technology, Faculty of Management, Poland, EU, \\ marek.krynke@wz.pcz.pl,krzysztof.mielczarek@wz.pcz.pl,marta.jagusiak-kocik@wz.pcz.pl \\ ${ }^{4}$ Cracow University of Technology, Krakow, Poland, EU, anna.kielbus@pk.edu.pl
}

\section{https://doi.org/10.37904/metal.2021.4302}

\begin{abstract}
A large variety of types of rotation mechanisms used in mechanical engineering requires the designers of such machines to be able to select appropriate methods of their calculation. An important issue in the design of these mechanisms is to define the basic characteristics of these devices as well as areas of application. The article presents the factors influencing the quality improvement and streamlining the process of calculating the load capacity of toothed roller bearings used in the mechanisms of rotation of the bodies of heavy machines. The purpose of the considerations is to identify and eliminate sources of errors in determining the characteristics of the slewing bearing capacity. The result of the research is the determination of the risk of errors and the development of guidelines for designers of slewing bearings.
\end{abstract}

Keywords: Quality, FMEA, Ishikawa, slewing bearing

\section{INTRODUCTION}

For modern organizations, quality is one of the most important bases for existence on the market. It is a very broad concept which, from the customer's point of view, guarantees a high level of purchased goods. From the organization's point of view, this requires achieving and maintaining a high level of the product [1-3]. In the current era of the free market, achieving the best possible level of quality is the most important thing for the organization. Carry out such a task, organizations use various tools and methods of quality management [4-6]. Quality management methods are more focused on the analysis of the collected data, while tools are used to collect information about a given product $[7,8]$. It is important to be able to see the information contained in the method and use it to improve other processes or products. Modern technology constantly increases the requirements for products. It is especially important due to their reliability and other performance parameters, such as increasing the permissible load capacity and durability. An example of such a product is a slewing ring (Figure 1).

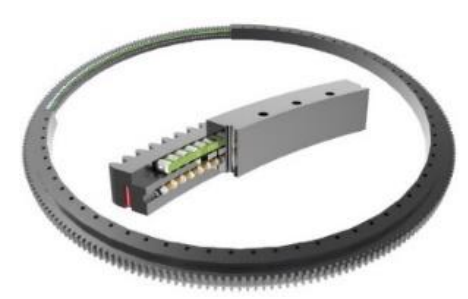

Figure 1 Double-row slewing rings roller/ball combination bearings

Slewing roller bearings are most often used as devices connecting two structures of a working machine, most often a chassis with a rotating body [9]. These bearings have to meet safety criteria to withstand extreme loads 
and environmental factors throughout their service life [10]. In contrast to general purpose rolling bearings, they show several distinctiveness. The most important ones are their diameter, which can vary from $0.5 \mathrm{~m}$ to $15 \mathrm{~m}$, a large number of rolling parts and the transmission of high loads at relatively low operating speeds. The basic quantity that determines the working conditions of the slewing rings is their static load capacity. The static load capacity is defined by an appropriate characteristic built in the coordinate system: axial force $Q$ - high titling moment $M$ [11]. An important issue in shaping such rotation mechanisms is to define the basic characteristics of these devices and the areas of their application [12]. The article presents the factors improving the quality and the process of calculating the load capacity of a slewing bearing. The purpose of the considerations is to identify and eliminate sources of errors in determining the load capacity characteristics for a slewing bearing. The result of the conducted research is the determination of the risk of errors and advice for the designers of slewing bearings.

\section{FACTORS DECIDING ABOUT THE CAPACITY AND DURABILITY OF THE SLEWING BEARINGS}

Slewing bearing is a subgroup of rolling element bearing commonly used in large industrial machineries such as turntable, steel mill cranes, offshore cranes, rotatable trolley, excavators, stackers, swing shovels, and ladle cars. A slewing bearing is basically a bearing with a gear wheel integrated in the inner or outer ring, which is subjected to a complex set of heavy loads. Wind turbines have become a significant group of devices. In addition, slewing bearings are used in military vehicles, radar antennas, sewage treatment plants, tunnel cutters, motor vehicle chassis, or in medical devices or amusement parks. A slewing bearing is basically a bearing with a gear wheel integrated in the inner or outer ring, which is subjected to a complex set of heavy loads. They typically support high axial $Q$, high tilting moment $M$ and high radial load $H$. Slewing bearings are often a critical component of the device. Bearing failure can cause large losses due to unplanned production downtime. Moreover, its replacement, due to its large dimensions, may take several months [11]. In order to prevent unplanned downtime, a condition monitoring and prognosis method is needed. There are many types of slewing bearings depending on the number of rows and in the type of rolling elements. Thus, there are bearings with one, two and three rows, and the rolling elements can be balls or cylindrical rollers [13]. Slewing bearings are designed and manufactured for a specific application and requires knowledge of the design of the device on which the bearing will work, the approximate dimensions of the bearings, the diameters of the bearing rings mounting screws locations, as well as all the types and magnitude of loads that are transmitted through the bearing (Figure 2) [14].

a)

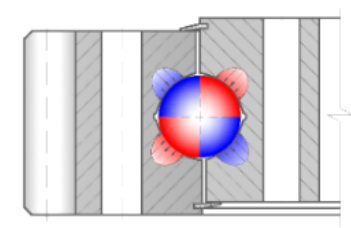

b)

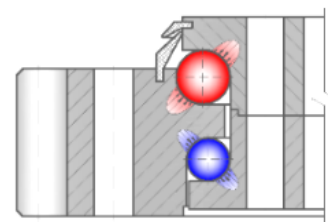

c)

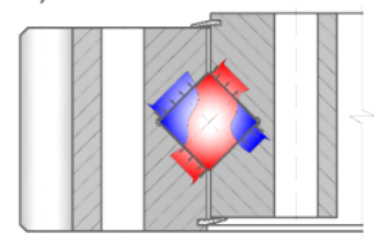

d)

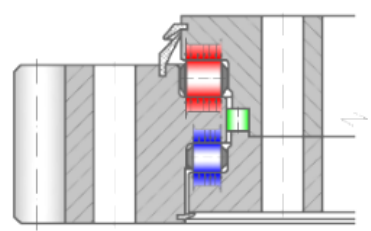

Figure 2 Basic types of slewing bearings: a) single-row ball bearings, b) double-row ball bearings, c) cross single-row roller, d) three-row roller

The Ishikawa diagram (Figure 3) was used to describe the factors determining the load capacity and durability of slewing bearings. The Ishikawa diagram, as one of the instruments of quality management, is a method for solving problems based on a cause and effect analysis. The Ishikawa diagram should be used in the case of problems where several causes are suspected or we are unable to determine the potential cause at all. Common uses of the Ishikawa diagram are product design and quality defect prevention to identify potential factors causing an overall effect. Each cause or reason for imperfection is a source of variation. Causes are usually grouped into major categories to identify and classify these sources of variation [15]. The main purpose of calculating slewing bearings is to determine their static load capacity and, consequently, to prepare the 
bearing characteristics, i.e. diagrams of the operating area limited by the permissible load curves for the function $M(Q, H)$. The load capacity of slewing bearings is determined by various calculation methods. The analysis of the actual operating conditions of the bearing shows that the computer aided design of slewing bearings should additionally take into account the deformation of the supporting structure resulting from its support. A simplified design diagram of a slewing bearing is shown in Figure 4.

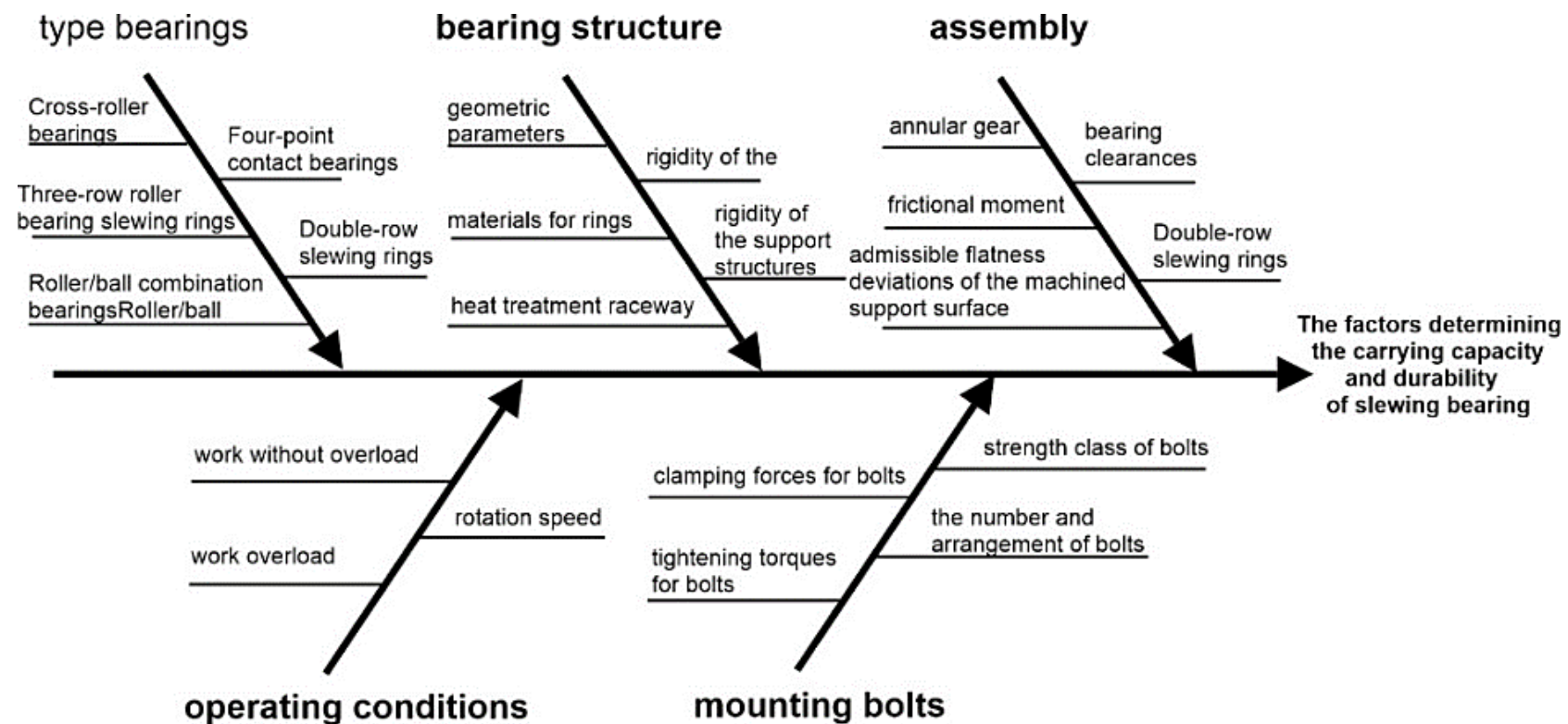

Figure 3 Factors decisive about the load capacity and durability of slewing bearings

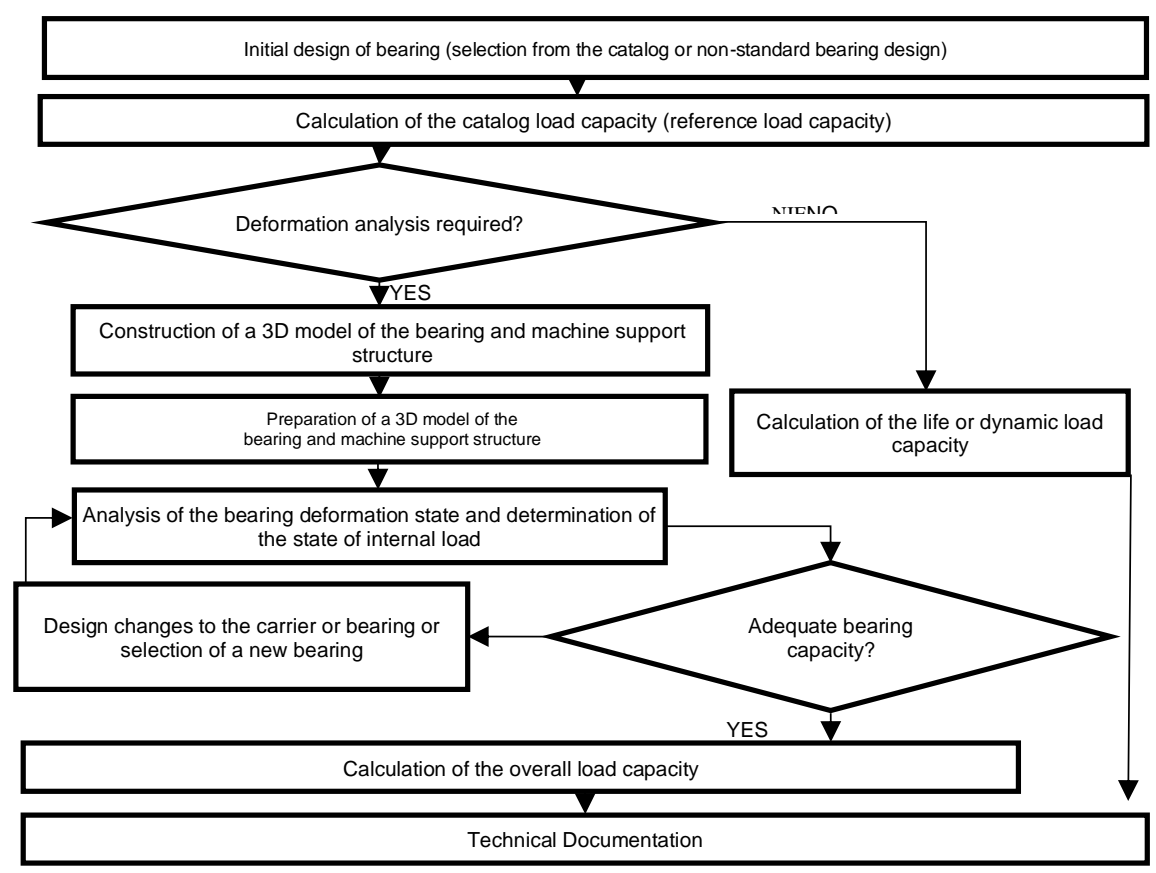

Figure 4 Diagram of a computer system for calculating the load capacity of slewing bearing

The simplest calculation models allow to determine the bearing characteristics assuming a number of simplifications. A consequence of the simplifications used is inaccurate estimation of the actual bearing capacity $[9,13,14]$. More complex computational models require the use of a computer system for calculating such bearings [13]. The load capacity of slewing bearings depends on a number of factors, such as [12]: 
- flexibility of bolts securing bearing rings in the structure of the working machine,

- coefficient of adhesion of the balls to the raceway,

- nominal angle of action of the forces transmitted by the rolling elements, and its change when the bearing is loaded,

- flexibility of bearing rings,

- $\quad$ sizes of the contact zones of the rolling elements with raceways,

- fill factor of the rolling circumference of the bearing raceway,

- bearing clearance (including preload in the case of a triple row roller bearing with split rings).

\section{RISK OF ERRORS IN DETERMINING THE LOAD CAPACITY}

Table 1 Analysis of the causes and effects of errors in calculating the load capacity of toothed slewing bearings

\begin{tabular}{|c|c|c|c|c|c|c|c|c|}
\hline \multirow{2}{*}{ Potential error } & \multirow{2}{*}{$\begin{array}{l}\text { The effects of } \\
\text { errors }\end{array}$} & \multirow{2}{*}{$\begin{array}{l}\text { The cause } \\
\text { of the error }\end{array}$} & \multirow{2}{*}{$\begin{array}{l}\text { Research } \\
\text { methods }\end{array}$} & \multicolumn{4}{|c|}{$\begin{array}{c}\text { The current } \\
\text { state }\end{array}$} & \multirow{2}{*}{ Recommended action } \\
\hline & & & & $\mathbf{R}$ & $\mathbf{z}$ & W & RPN & \\
\hline $\begin{array}{l}\text { Ignoring bearing } \\
\text { clearance }\end{array}$ & $\begin{array}{c}\text { Incorrect } \\
\text { meshing } \\
\text { geometry of } \\
\text { gear ring and } \\
\text { pinion } \\
\text { Revaluation } \\
\text { static load } \\
\text { capacity }\end{array}$ & $\begin{array}{l}\text { Simplification of } \\
\text { computational models } \\
\text { without the possibility of } \\
\text { introducing bearing } \\
\text { clearance }\end{array}$ & $\begin{array}{l}\text { Calculation of } \\
\text { replacement } \\
\text { characteristics for } \\
\text { rolling elements }\end{array}$ & 6 & 5 & 3 & 90 & $\begin{array}{l}\text { Clearance introduced into the } \\
\text { computational model by moving the } \\
\text { replacement material characteristic } \\
\text { for rolling elements }\end{array}$ \\
\hline $\begin{array}{c}\text { Ignoring changes } \\
\text { in the nominal } \\
\text { contact angle of } \\
\text { balls }\end{array}$ & $\begin{array}{c}\text { The risk of } \\
\text { damaging the } \\
\text { edges of } \\
\text { raceway bearing }\end{array}$ & $\begin{array}{c}\text { Calculations of ball } \\
\text { bearings on models of } \\
\text { computation relating to } \\
\text { roller bearings, in which } \\
\text { there is change of contact } \\
\text { angle } \\
\end{array}$ & $\begin{array}{c}\text { Classical and } \\
\text { numerical model for } \\
\text { the calculation of } \\
\text { bearings }\end{array}$ & 7 & 4 & 6 & 196 & $\begin{array}{l}\text { In computational models, the balls } \\
\text { should be replaced element special } \\
\text { which allows in accordance with the } \\
\text { change in the angle of operation of } \\
\text { the parts of rolling due to portable } \\
\text { loads }\end{array}$ \\
\hline $\begin{array}{l}\text { Ignoring the bolts } \\
\text { of bearing ring }\end{array}$ & $\begin{array}{l}\text { Revaluation } \\
\text { static load } \\
\text { capacity }\end{array}$ & $\begin{array}{c}\text { Simplification of the model } \\
\text { computing with respect } \\
\text { mounting bolts }\end{array}$ & $\begin{array}{c}\text { Computation } \\
\text { models without the } \\
\text { possibility of input } \\
\text { the bolts }\end{array}$ & 5 & 3 & 6 & 75 & $\begin{array}{c}\text { In numerical calculations the finite } \\
\text { element method to model the bolts } \\
\text { with beam elements with } \\
\text { pretension }\end{array}$ \\
\hline $\begin{array}{l}\text { lgnoring the } \\
\text { deviation from } \\
\text { flatness of the } \\
\text { surface retaining } \\
\end{array}$ & $\begin{array}{l}\text { Revaluation } \\
\text { static load } \\
\text { capacity }\end{array}$ & $\begin{array}{l}\text { The assumptions of the } \\
\text { model calculation }\end{array}$ & $\begin{array}{c}\text { Classical } \\
\text { computation } \\
\text { models bearings }\end{array}$ & 6 & 4 & 8 & 192 & $\begin{array}{l}\text { The deviation from flatness must be } \\
\text { considered in geometry of the } \\
\text { model calculation, concerning the } \\
\text { seats of the bearing }\end{array}$ \\
\hline $\begin{array}{l}\text { Ignoring the } \\
\text { flexibility of } \\
\text { bearing rings }\end{array}$ & $\begin{array}{l}\text { Revaluation } \\
\text { static load } \\
\text { capacity } \\
\end{array}$ & $\begin{array}{l}\text { The assumptions made in } \\
\text { the model computing }\end{array}$ & $\begin{array}{c}\text { Classical com- } \\
\text { putation models } \\
\text { bearings }\end{array}$ & 5 & 4 & 6 & 120 & $\begin{array}{c}\text { Construction of numerical models } \\
\text { using FEM }\end{array}$ \\
\hline $\begin{array}{l}\text { Ignoring the } \\
\text { flexibility of } \\
\text { systems of re- } \\
\text { ference and of } \\
\text { bearing used for } \\
\text { machine }\end{array}$ & $\begin{array}{l}\text { Revaluation } \\
\text { static load } \\
\text { capacity }\end{array}$ & $\begin{array}{c}\text { Lack of knowledge of the } \\
\text { geometry of supporting } \\
\text { structures at the stage of } \\
\text { calculation of the bearing } \\
\text { capacity }\end{array}$ & $\begin{array}{c}\text { Classical } \\
\text { computation } \\
\text { models bearings }\end{array}$ & 8 & 6 & 9 & 432 & $\begin{array}{c}\text { It is necessary to know the } \\
\text { structure of bearing installation and } \\
\text { execute a computational model } \\
\text { taking into account the entire } \\
\text { structure of the machine relative to } \\
\text { the site of rotation }\end{array}$ \\
\hline
\end{tabular}

The risk related to the overestimation of the load capacity of toothed slewing bearings results from the adopted simplifications in the calculation models. The FMEA method was used to determine the degree of risk [16]. FMEA (Failure Mode and Effect Analysis) means the analysis of the causes and effects of defects. It is one of the methods used to minimize or eliminate the effects of defects that may occur in construction and manufacturing processes. The purpose of the FMEA is in particular [17,18]: consistent and permanent elimination of product or process defects by identifying the reasons for their occurrence and appropriate effective remedial measures; preventing the occurrence of already identified defects as well as those provided 
for by using conclusions from previous analyzes. Table 1 shows the individual factors and the risks that occur if they are not taken into account when calculating the load capacity of toothed slewing bearings $[11,13]$. In the research, the risk was determined by defining the criteria for selecting the coefficients, i.e .: $\mathrm{R}$ - the risk of error occurrence, $\mathrm{Z}$ - the significance of the error and $\mathrm{W}$ - the difficulty of including the error in the calculations. However, the priority number of risk was determined using the dependence:

$R P N=R \cdot Z \cdot W$

The greatest risk associated with incorrect estimation of the load capacity of toothed slewing bearings concerns the failure to take into account the susceptibility of support and load-bearing structures for the machine used. When calculating the load capacity, it is also important to take into account the flexibility of the bearing rings as well as the bearing clearances. The contact angle of the rolling elements also has a great influence on the load capacity of ball bearings

\section{CONCLUSION}

The paper presents an analysis of the quality of the methods for calculating the static load capacity of slewing bearings. Classical calculation models of toothed slewing bearings, due to their complexity, must be subject to various simplification. This also applies to numerical models using the finite element method. These simplifications contribute to the inaccurate determination of the load capacity of slewing bearings. The greatest risk of error related to the estimation of the load capacity of toothed slewing bearings occurs when they are mounted on supporting structures that do not provide adequate stiffness of the seats. The deformation of bearing rings caused by their limited stiffness has a very significant impact on the value of loads that can be transferred by the bearing. For this reason, when determining the catalog bearing capacity, it is important to take into account the flexibility of the rings, their fastening, as well as the susceptibility of the entire bearing and support structures of the working machine. It should also be remembered that during the operation of the bearing, depending on the intensity of the raceway wear process, the clearances in the bearing increase. Excessive bearing clearances contribute to the deterioration of the meshing conditions of the pinion with the toothed rim due to the uneven load distribution along the tooth line, and also reduce the bearing capacity. It can therefore be concluded that taking into account all the factors influencing the bearing capacity allows for a more accurate determination of the bearing's safety factor already at the design stage. The methods described in the article are of interest to many technical areas, including engineering of production [19-21] and service [22-24] processes, biotechnology [25], coating technologies [26] and corrosion resistance [27,28]. They can also be inspiring for material sciences [29], mechanical analysis [30] and analytical methods [31,32].

\section{REFERENCES}

[1] MAZUR, M. Analysis of production incompatibilities and risk level in series production of assembly elements for the automotive industry. MATEC Web of Conf. 2018, vol. 183, art. 03011.

[2] SIWIEC, D., PACANA, A. Method of improve the level of product quality. Production Engineering Archives. 2021, vol. 27, no. 1, pp. 1-7.

[3] PACANA, A., CZERWIŃSKA, K. Improving the quality level in the automotive industry. Production Engineering Archives. 2020, vol. 26, no. 4, pp. 162-166

[4] KLIMECKA-TATAR, D., PAWŁOWSKA, G., RADOMSKA, K. Preliminary quality control of magnetic materials for applications in restorative medicine-quantitative analysis of structural homogeneity of RE-M-B/polymer composites. Manufacturing Technology. 2020, vol. 20, no. 1, pp. 49-54.

[5] BORKOWSKI, S., KNOP, K. Challenges faced in modern quality inspection. Management and Production Engineering Review. 2016, vol. 7, no. 3, pp. 11-22.

[6] ULEWICZ, R., JELONEK, D., MAZUR, M. Implementation of Logic Flow in Planning and Production Control. Management and Production Engineering Review. 2016, vol. 7, no. 1, pp. 89-94. 
[7] SZATANIAK, P., NOVY, F., ULEWICZ, R. HSLA steels - comparison of cutting techniques. In: METAL 2014, 23rd Int. Conf. on Metall. and Mater. 2014, pp. 778-783.

[8] ENNOURI, W. Risk Management Applying FMEA-STEG Case Study. Polish Journal of Management Studies. 2015, vol. 11, no. 1, pp. 56-67.

[9] GUNIA, D., SMOLNICKI, T. The Influence of the Geometrical Parameters for Stress Distribution in Wire Raceway Slewing Bearing. Archive of Mechanical Engineering. 2017, vol. 64, no. 3, pp. 315-326.

[10] KRYNKE, M., KRZYSZTOF, K. Analysis of causes and effects errors in calculation of rolling slewing bearings capacity. Production Engineering Archives. 2016, vol. 12, no. 3, pp. 38-41.

[11] ŚPIEWAK, S. Methodology for calculating the complete static carrying capacity of twin slewing bearing. Mechanism and Machine Theory. 2016, vol. 101, pp. 181-194.

[12] KRYNKE, M., ULEWICZ, R. Analysis of the influence of slewing bearing mounting on their static load capacity. Transportation Research Procedia. 2019, vol. 40, pp. 745-750.

[13] KRYNKE, M. Modelling of Roller-raceway Contacts in the Slewing Bearing Taking into Account Asymmetrical Load Transfer Through a Roller. Manufacturing Technology. 2019, vol. 19, no. 6, pp. 979-983.

[14] KRYNKE, M., BORKOWSKI, S., SELEJDAK, J. Analysis of influence of bearing clearance on the static carrying capacity of multi-row slewing bearings. Periodica Polytechnica Transport. Engin. 2014, vol. 42, no. 1, pp. 43-48.

[15] CZAJKOWSKA, A., INGALDI, M. Structural Failures Risk Analysis as a Tool Supporting Corporate Responsibility. Journal of Risk and Financial Management. 2021, vol. 14, no. 187, p. 20.

[16] ULEWICZ, R. Practical Application of Quality Tools in the Cast Iron Foundry. Manufacturing Technology. 2014, vol. 14 , no. 1 , pp. 104-111.

[17] MIDOR, K. An analysis of the causes of product defects using quality management tools. Management Systems in Production Engineering. 2014, vol. 4, no. 16, pp. 162-167.

[18] KAPUSTKA, K., ZIEGMANN, G., KLIMECKA-TATAR, D., NAKONCZY, S. Process Management and Technological Challenges in the Aspect of Permanent Magnets Recovery - the Second Life of Neodymium Magnets. Manufacturing Technology. 2020, vol. 20, no. 5, pp. 617-624.

[19] PACANA, A., CZERWIŃSKA, K., DWORNICKA, R. Analysis of non-compliance for the cast of the industrial robot basis. In: METAL 2019: 28th Int. Conf. on Metall. and Mater. Ostrava: TANGER, 2019, pp. 644-650.

[20] ANTOSZ, K., PACANA, A. Comparative analysis of the implementation of the SMED method on selected production stands. Tehnicki Vjesnik. 2018, vol. 25, pp. 276-282.

[21] PACANA A., CZERWIŃSKA K., BEDNAROWA L.. Comprehensive improvement of the surface quality of the diesel engine piston. Metalurgija. 2018. vol. 58, pp. 329-332.

[22] BARYSHNIKOVA, N., KIRILIUK, O., KLIMECKA-TATAR, D. Management approach on food export expansion in the conditions of limited internal demand. Polish J. Manage. Stud. 2020, vol. 21, pp.101-114.

[23] ULEWICZ, R. Application of servqual method for evaluation of quality of educational services at the university of higher education [Zastosowanie metody servqual do oceny jakości usług edukacyjnych na uczelni wyższej]. Polish J. Manage. Stud. 2014, vol. 9, pp. 254-264.

[24] MAJEWSKI, G., ORMAN, Ł.J., TELEJKO, M., RADEK, N., PIETRASZEK, J., DUDEK, A. Assessment of thermal comfort in the intelligent buildings in view of providing high quality indoor environment. Energies. 2020, vol. 13, art. 1973.

[25] SKRZYPCZAK-PIETRASZEK, E., URBANSKA, A., ZMUDZKI, P., PIETRASZEK, J. Elicitation with methyl jasmonate combined with cultivation in the Plantform ${ }^{\mathrm{TM}}$ temporary immersion bioreactor highly increases the accumulation of selected centellosides and phenolics in Centella asiatica (L.) Urban shoot culture. Engineering in Life Sciences. 2019. vol. 19, pp.931-943.

[26] MICHNA, S., NAPRSTKOVA, N., KLIMECKA-TATAR, D. Research the causes of surface stains after eloxal coating for the profile from the AIMgSi alloy using substructural analysis. Manuf. Technol. 2015, vol.15, pp.620624.

[27] LIPINSKI, T. Corrosion effect of $20 \% \mathrm{NaCl}$ solution on basic carbon structural S235JR steel. Engineering for Rural Development. 2017, vol. 16, pp. 1069-1074. 
[28] LIPINSKI, T., KARPISZ, D. Effect of animal slurry on carbon structural S235JR steel at $303 \mathrm{~K}$. Engineering for Rural Development. 2020, vol. 19, pp. 1482-1487.

[29] SZCZOTOK, A., PIETRASZEK, J., RADEK, N. Metallographic Study and Repeatability Analysis of Y' Phase Precipitates in Cored, Thin-Walled Castings Made from IN713C Superalloy. Arch. Metall. Mater. 2017, vol. 62, pp. 595-601.

[30] KOZIEŃ, M.S., WICIAK, J. Passive structural acoustic control of the smart plate - FEM simulation. Acta Phys. Pol. A. 2010, vol. 118, pp. 1186-1188.

[31] PIETRASZEK, J., GASDEK-MOSZCZAK, A., RADEK, N. The estimation of accuracy for the neural network approximation in the case of sintered metal properties. Studies in Computational Intelligence. 2014, vol. 513, pp. 125-134.

[32] PIETRASZEK, J., GOROSHKO, A. The heuristic approach to the selection of experimental design, model and valid pre-processing transformation of DoE outcome. Adv. Mater. Res.-Switz. 2014, vol. 874, pp. 145-149. 